\title{
Penerapan Model Pembelajaran Discovery Learning untuk Meningkatkan Motivasi dan Hasil Belajar Fisika Peserta Didik Kelas XI IPA 3 SMA N 6 Pekanbaru Semester Genap
}

\author{
L. Br Hotang \\ SMA Negeri 6 Pekanbaru Riau \\ *email: lasmahotang@gmail.com
}

Received: March 16 th, 2019. Accepted: June 2nd, 2019. Published: August 29th, 2019

\begin{abstract}
Abstrak
Pengetahuan yang diperoleh peserta didik dalam kelas hanya bertahan sesaat dan tidak mampu menghubungkan materi pelajaran dengan kehidupan nyata. Tujuan penelitian ini adalah untuk meningkatkan motivasi dan hasil belajar fisika peserta didik kelas XI IPA 3 SMA N 6 Pekanbaru. Prosedur penelitian tindakan kelas ini menggunakan 2 siklus dan dilakukan ulangan harian di akhir dari setiap siklus untuk melihat peningkatan hasil belajar. Motivasi belajar peserta didik dilihat dari angket respons yang diberikan di akhir siklus. Hasil analisis menunjukkan ratarata ulangan harian pada siklus I adalah 65.11 dengan kategori cukup; 14 peserta didik tuntas (38.88\%) dan 22 peserta didik belum tuntas (61.11\%). Pada siklus II diperoleh rata-rata 78.47 dengan kategori baik; 33 peserta didik tuntas $(91.7 \%)$ dan 3 peserta didik belum tuntas $(8.3 \%)$. Hasil analisis angket respons menunjukkan peserta didik termotivasi dalam mengikuti pelajaran, dibuktikan dengan nilai respons rata-rata lebih dari 70\%. Berdasarkan hasil penelitian dapat disimpulkan bahwa penerapan model pembelajaran discovery learning dapat meningkatkan motivasi dan hasil belajar fiska bagi peserta didik kelas XI IPA 3 SMAN 6 Pekanbaru.
\end{abstract}




\begin{abstract}
Knowledge obtained by students in the class only survived for a while and were unable to relate the subject matter to real life. The procedure for classroom action research uses 2 cycles and the end of each cycle is repeated daily to see the increase in motivation and learning outcomes. Students' learning motivation find from the questionnaire given at the end of the cycle. The results of the analysis showed the average of daily tests in the first cycle was 65.11 with a sufficient category; 14 students complete $(38.88 \%)$ and 22 students have not yet completed $(61.11 \%)$ and in the second cycle 78.77 in good categories; 33 students complete $(91.7 \%)$ and 3 students have not yet finished $(8.3 \%)$. The results of the questionnaire analysis showed students were motivated to the lessons, as evidenced by the average response value of more than $70 \%$. Based on the results of the study it can be concluded that discovery learning models can increase the motivation and physical learning outcomes for students of class XI IPA 3 of SHS 6 Pekanbaru. C2019PERJ
\end{abstract}

Keywords: discovery learning, learning outcomes, motivation to learn. 


\section{PENDAHULUAN}

Peraturan Pemerintah No 19 Tahun 2005 Bab 1 Pasal 1 Ayat 6 menyatakan bahwa standar proses pendidikan berkaitan dengan pelaksanaan pembelajaran pada satu satuan pendidikan untuk mencapai standar kompetensi lulusan (Sanjaya, 2008). Standar proses pendidikan memiliki peran yang sangat penting dalam peningkatan kualitas pendidikan. Seideal apapun standar isi dan standar lulusan serta standarstandar lainnya, tanpa didukung oleh standar proses yang memadai, maka standar-standar tersebut tidak akan memiliki nilai.

Standar proses merupakan kompenen penting yang harus dikuasai guru. Keberhasilan pelaksanaaan proses pendidikan sangat bergantung pada guru sebagai ujung tombak (Destalina, Ali \& Palloan, 2019). Oleh karena itu kemampuan guru harus dibenahi sesuai dengan perkembangan zaman yang serba canggih. Guru juga harus menguasai berbagai strategi pembelajaran (Sahara \& Sani, 2016). Guru harus mampu memilih strategi yang dianggap tepat, oleh sebab itu guru perlu memahami prinsip-prinsip umum penggunaan strategi yang berorientasi pada tujuan, aktivitas, individualitas, dan integritas (Saidatunnisa, Hamid \& Wahyuni, 2016).

Berbagai strategi yang dimiliki guru dapat dipakai untuk mengembangkan berbagai kompetensi peserta didik (Kusuma, Indrawati \& Harijanto, 2015). Kompetensi yang dirancang oleh pemerintah mengarahkan peserta didik agar memiliki kecerdasan, baik kognitif, keterampilan, maupun afektif. Pembelajaran didesains untuk membelajarkan peserta didik, artinya sistem pembelajaran menempatkan peserta didik sebagai subjek belajar (Khamidah \& Mustikasari, 2019). Pembelajaran ditekankan atau berorientasi pada aktivitas peserta didik (Aprilia \& Mulyaningsih, 2014).

Pembelajaran yang berorientasi pada peserta didik membuat peserta didik secara aktif dapat mengembangkan potensi dirinya. Peserta didik yang mampu berinteraksi dengan baik akan mampu menyerap setiap ilmu pengetahuan dan membuat pengetahuan tersebut menjadi bermakna dengan pemahaman yang lebih baik (Fitri \& Derlina, 2015). Selain itu, kegiatan pembelajaran harus dapat menumbuh kembangkan 
seluruh struktur pengetahuan sehingga peserta didik sendiri menemukan apa yang menjadi kebutuhannya dalam belajar serta mampu merealisasikan ilmunya untuk menyelesaikan masalah dalam kehidupan sehari-hari. Peserta didik akan mampu menjawab setiap kesulitan dengan ilmu yang diperoleh (Singgih \& Suparwoto, 2018). Hal tersebut dimungkinkan apabila selama proses pembelajaran kerja otak peserta didik dirangsang secara maksimal, yaitu untuk selalu berani bereksplorasi (Sari \& Harjono, 2016). Peserta didik akan memiliki kemampuan untuk mencari, mengolah data, mengkonstruksi, dan kemudian menggunakan pengetahuan.

Kenyataan di lapangan menunjukkan bahwa siswa mengingat materi pelajaran ketika proses pembelajaran berlangsung di kelas saja. Artinya setelah selesai kegiatan belajar mengajar, peserta didik cenderung lupa tentang hal yang telah dipelajari (Tompo, Ahmad \& Moris, 2016). Hasil wawancara dengan peserta didik menunjukkan bahwa sebagian besar peserta didik tidak mampu manghubungkan materi yang diperoleh di kelas dengan kejadian di kehidupan nyata. Misalnya, penerapan fisika Hukum Newton I yaitu penggunaan sabuk pengaman di mobil; penerapan pembiasan, yaitu mengapa sungai siang hari kelihatan dangkal; penerapan perpindahan kalor, yaitu perlunya rumah memiliki ventilasi yang cukup; dan materi fisika lainnya. Selain itu, minat peserta didik dalam belajar fisika juga kurang. Hal ini dibuktikan dari hasil ulangan harian yang dilakukan sebelumnya di kelas $X$ IPA 3 untuk materi Termodinamika. Hasil yang diperoleh adalah dari 36 peserta didik, hanya 7 (19.4\%) peserta didik yang mencapai ketuntasan minimum, dan 29 (80.5\%) lainnya belum tuntas. Hasil dari ulangan harian ini menunjukkan bahwa peserta didik belum menggunakan keterampilan intelektualnya secara maksimal.

Motivasi peserta didik untuk mengikuti pembelajaran, kegiatan diskusi, dan mengerjakan penugasan masih tegolong rendah. Ketika dihadapkan pada suatu soal, misalnya soal fisika, peserta didik harus mengingat bermacam-macam hal yang berkenaan dengan jenis-jenis belajar seperti diskriminasi, rangkaian, klasifikasi, menggunakan aturan atau hukum dan pemecahan masalah (Hanafi, 2016). Nilai ulangan harian yang rendah juga 
dipengaruhi oleh faktor proses pembelajaran yang cenderung dikuasi oleh guru. Peserta didik hanya mendapat informasi, dan bila dilakukan diskusi umumnya dikuasi oleh beberapa peserta didik yang pintar saja. Hal tersebut mengakibatkan proses pembelajaran tidak berjalan baik dan pemahaman peserta didik akan materi juga menjadi kurang kuat, serta rendahnya intelektual peserta didik (Decaprio, 2002).

Proses pegembangan keterampilan intelektual tidak cukup hanya mengenal atau mengingat kembali, tetapi perlu pemahaman untuk mengaitkan materi yang secara utuh. Agar peserta didik dapat belajar lebih aktif dan mampu memahami pelajaran dengan baik serta mampu menyelesaikan masalah sehari-hari yang berkaitan dengan konsep fisika, maka guru harus memunculkan strategi yang tepat dalam memotivasi peserta didik sehingga dapat meningkatkan keterampilan intelektual.

Model pembelajaran discovery learning menekankan pada penemuan konsep atau prinsip yang sebelumnya belum diketahui oleh peserta didik. Masalah yang dihadapkan kepada peserta didik semacam masalah yang direkayasa oleh guru. Penerapan model pembelajaran discovery learning bertujuan untuk merubah kondisi belajar yang pasif menjadi aktif dan kreatif, dengan mengubah pembelajaran teacher centered ke student centered. Pembelajaran yang awalnya dilakukan dengan penjelasan materi oleh guru, dilanjutkan pemberian latihan soal diubah menjadi peserta didik yang mengikuti pemebelajaran secara mandiri melalui kegiatan eksplorasi dan meemukan konsep. Teacher centered juga merubah modus ekspository peserta didik yang hanya menerima informasi secara keseluruhan dari guru ke modus discovery peserta didik menemukan informasi sendiri.

Berdasarkan uraian tersebut maka diperlukan suatu perbaikan dalam proses pembelajaran yang membuat peserta didik menjadi pusat dalam proses pembelajaran Oleh karena itu perlu dilakukan inovasi dalam meningkatkan konsep pengetahuan dan pemahaman peserta didik dengan melakukan Penelitian Tindakan Kelas (PTK). Penelitian ini bertujuan untuk meningkatkan motivasi dan hasil belajar fisika peserta didik Kelas XI IPA.3 SMAN 6 Pekanbaru semester genap T.A 2017/2018 dengan 
menerapkan model pembelajaran discovery learning.

\section{METODE}

Desain penelitian ini adalah Penelitian Tindakan Kelas (PTK) yang dilaksanakan dalam bentuk siklus berulang dengan empat tahapan utama kegiatan yaitu:

a. Tahap Perencanaan

Tahapan ini dilakukan dengan membuat perencaan pembelajaran dengan model pembelajaran discovery learning. Pembelajaran direncanakan selama empat kali pertemuan yang terdiri atas tiga pertemuan untuk materi dan satu pertemuan untuk ulangan harian. Proses pembelajaran dan ulangan harian dilakukan dalam ruang kelas.

b. Tahap Pelaksanaan

Pelaksanaan siklus I diawali mengajak peserta didik untuk berdoa dan mengecek kehadiran peserta didik. Selanjutnya peserta didik duduk dalam kelompok masing-masing, sementara guru menjelaskan kompetensi dasar, tujuan, dan indikator pembelajaran. Guru juga memperlihatkan gambar sebagai pembukaan materi secara umum. Proses pembelajaran yang dilakukan melalui penerapan model pembelajaran discovery learning adalah:
1) Stimulation

Guru memberikan beberapa pertanyaan dan menugaskan peserta didik membaca buku untuk menyediakan kondisi agar peserta didik dapat mengeksplorasi materi.

2) Problem statement

Guru memberi kesempatan kepada peserta didik untuk mengidentifikasi masalah dalam lembar kerja.

3) Data collection

Guru memberi kesempatan kepada peserta didik untuk mengumpulkan informasi sebanyak mungkin dengan melakukan eksperimen, wawacara, mengamati objek, maupun membaca literatur.

4) Data Processing

Guru memberi kesempatan kepada peserta didik untuk mengolah data yang telah diperoleh dari hasil eksperimen, wawancara, maupun observasi.

5) Verification

Guru memberi kesempatan kepada peserta didik untuk melakukan pemeriksaan secara cermat dengan menjawab permasalahan kembali dan kemudian mempresentasikan hasil diskusi.

6) Generalization

Guru bersama dengan peserta didik melakukan penarikan 
kesimpulan dari materi yang telah dipelajari.

c. Tahap Pengamatan

Pengamatan dilakukan untuk mengetahui efektifitas penerapan model pembelajaran discovery learning untuk meningkatkan motivasi dan hasil belajar fisika.

d. Tahap Refleksi

Tahapan ini dilakukan setelah pembelajaran siklus I selesai dilaksanakan. Setelah pelaksanaan pembelajaran pada siklus I, diharapkan terjadi halhal sebagai berikut:

1) Terdapat peningkatan motivasi dan hasil belajar peserta didik secara signifikan.

2) Peserta didik mampu mengaplikasikan konsep fisika di kehidupan nyata. Apabila hasil yang diperoleh pada siklus I belum dapat mencapai tujuan tersebut maka perlu dilakukan siklus II.

Data yang dikumpulkan pada penelitian ini adalah observasi pembelajaran, nilai ulangan harian dan angket respons dari peserta didik. Observasi pembelajaran dilakukan setiap pertemuan, ulangan harian dilakukan setelah selesai 1 kali siklus, sedangkan angket respons hanya diberikan 1 kali yaitu di akhir siklus. Pelaksanaan ulangan harian dilakukan di dalam kelas dibantu oleh teman sejawat untuk mengawasi peserta didik. Teknik analisis data menggunakan analisis data deskriptif kuantitatif melalui perhitungan statistik deskriptif dengan menentukan rata-rata dan persentase setiap indikator pengukuran.

\section{HASIL DAN PEMBAHASAN}

Peningkatan hasil belajar untuk tiap siklus dapat dilihat pada Tabel 1. Berdasarkan hasil yang disajikan pada Tabel 1 dapat disimpulkan terjadi peningkatan nilai rata-rata ulangan harian yaitu pada siklus I dengan kategori cukup, dan pada siklus II terjadi peningkatan sehingga termasuk kategori baik.

Tabel 1. Peningkatan Hasil Belajar Tiap Siklus

\begin{tabular}{ccc}
\hline \multirow{2}{*}{$\begin{array}{c}\text { Ketuntasan } \\
\text { Belajar }\end{array}$} & \multicolumn{2}{c}{ Tindakan } \\
\cline { 2 - 3 } & $\begin{array}{c}\text { Siklus I } \\
(\%)\end{array}$ & $\begin{array}{c}\text { Siklus II } \\
(\%)\end{array}$ \\
\hline Tuntas & 38.88 & 91.7 \\
\hline Tidak & 61.11 & 8.3 \\
Tuntas & & \\
\hline Rata-rata & 65.11 & 78.47 \\
\hline
\end{tabular}

Peningkatan hasil belajar dari siklus I ke siklus II ini menunjukkan bahwa penerapan model pembelajaran discovery learning mampu meningkatkan hasil belajar peserta didik. Hal ini dikarenakan model discovery 
learning dapat memfasilitasi peserta didik untuk belajar lebih mendalam, memahami konsep melalui penemuan sehingga konsep yang ditemukan dapat diingat lebih lama dibanding hanya menerima konsep secara pasif. Nilai ulangan yang diperoleh dari siklus I dan siklus II diuraikan pada sebaran seperti Tabel 2.

Pada akhir kegiatan siklus II, peserta didik diminta mengisi angket respons untuk mengetahui pendapat peserta didik terhadap model pembelajaran discovery learning. Hasil dari angket respons tersebut disajikan pada Tabel 3.

Tabel 2. Perbandingan Sebaran Nilai Ulangan Harian

\begin{tabular}{lcccc}
\hline \multirow{2}{*}{ Kategori } & \multicolumn{4}{c}{ Materi } \\
\cline { 2 - 5 } & \multicolumn{2}{c}{ Siklus I } & \multicolumn{3}{c}{ Siklus II } \\
\cline { 2 - 5 } & $\mathrm{N}$ & $\%$ & $\mathrm{~N}$ & $\%$ \\
\hline Amat baik & 4 & 11.1 & 10 & 27.8 \\
Baik & 10 & 7.8 & 23 & 63.9 \\
Cukup & 19 & 52.8 & 3 & 8.3 \\
Kurang & 3 & 8.3 & - & - \\
\hline
\end{tabular}

Hasil analisis angket respons yang telah diisi oleh peserta didik menunjukkan respon positif terhadap model pembelajaran discovery learning. Hal ini dapat dibuktikan dengan dengan pilihan jawaban pada setiap item pertanyaan yang diberikan mendapat persentase lebih dari 70\%. Hasil analisis tersebut menunjukkan motivasi belajar fisika peserta didik meningkat dari siklus I dibandingkan dengan siklus II.

Hasil belajar pada siklus I menunjukkan peserta didik belum maksimal dalam mengikuti proses pembelajaran dengan penerapan model pembelajaran discovery learning. Berdasarkan hasil tersebut maka guru perlu melakukan perbaikan dengan cara meningkatkan pembimbingan dan pengawasan dalam mengolah kelas sehingga peserta didik memahami secara utuh setiap langkah pembelajaran. Pada siklus I, kegiatan dalam kelompok masih dikuasai oleh peserta didik yang lebih pintar saja sehingga peserta didik yang lemah daya tangkapnya merasa kurang dihargai dan pada akhirnya mereka terpantau bermain-main (Mursell \& Nasution, 2010). Peran guru sebagai motivator perlu ditingkatkan agar peserta didik tidak merasa asing dan nyaman mengikuti model pembelajaran discovery learning. Guru perlu mengarahkan peserta didik yang lebih pandai agar membantu teman sekelompok ketika eksperimen maupun berdiskusi. 
Phy. Educ. Res. J. Vol. 1 No. 1 (2019), 56-68

Tabel 3. Hasil Analisis Data Angket Respons Peserta Didik

\begin{tabular}{|c|c|c|c|c|}
\hline \multirow{2}{*}{ Pernyataan } & \multicolumn{2}{|c|}{ Jawab } & \multicolumn{2}{|c|}{ Persentase } \\
\hline & Ya & Tidak & $\mathrm{Ya}$ & Tidak \\
\hline 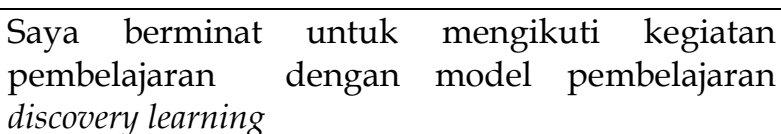 & 27 & 9 & 75 & 25 \\
\hline $\begin{array}{l}\text { Saya merasa senang selama mengikuti tahapan } \\
\text { belajar pada model pembelajaran discovery } \\
\text { learning. }\end{array}$ & 28 & 8 & 78 & 22 \\
\hline $\begin{array}{l}\text { Model pembelajaran discovery learning membuat } \\
\text { peserta didik mampu berpikir kristis untuk } \\
\text { memahami konsep fisika }\end{array}$ & 29 & 7 & 81 & 19 \\
\hline $\begin{array}{l}\text { Saya setuju } \\
\begin{array}{l}\text { pokok } \\
\text { menggunakan } \\
\text { learning }\end{array}\end{array}$ & 30 & 6 & 83 & 17 \\
\hline $\begin{array}{l}\text { Saya lebih paham dengan model pembelajaran } \\
\text { discovery learning }\end{array}$ & 28 & 8 & 78 & 22 \\
\hline $\begin{array}{l}\text { Saya baru mengenal dan menganggap model } \\
\text { pembelajaran discovery learning termasuk baru } \\
\text { dan menarik. }\end{array}$ & 34 & 2 & 94 & 6 \\
\hline $\begin{array}{l}\text { Saya merasa konsep materi ciri-ciri gelombang } \\
\text { mekanik, gelombang berjalan dan gelombang } \\
\text { stasioner sangat berkaitan dalam kehidupan } \\
\text { sehari-hari }\end{array}$ & 30 & 6 & 83 & 17 \\
\hline $\begin{array}{l}\text { Model pembelajaran discovery learning membuat } \\
\text { peserta didik lebih percaya diri di depan orang } \\
\text { lain }\end{array}$ & 30 & 6 & 83 & 17 \\
\hline $\begin{array}{l}\text { Tahapan belajar dalam model pembelajaran } \\
\text { discovery learning membuat peserta didik lebih } \\
\text { mengerti kaitan antara konsep materi dengan } \\
\text { kehidupan sehari hari. }\end{array}$ & 31 & 5 & 86 & 14 \\
\hline $\begin{array}{l}\text { Model pembelajaran discovery learning membuat } \\
\text { peserta didik lebih mampu belajar mandiri dan } \\
\text { terampil }\end{array}$ & 32 & 4 & 89 & 11 \\
\hline
\end{tabular}

Sebagai pembimbing yang harus terampil dalam baik, guru harus memiliki merencanakan pembelajaran, dan pemahaman tentang potensi dan ahli dalam memberi bantuan gaya belajar peserta didik. Guru kepada peserta didik sehingga 
peserta didik memiliki kemampuan mengembangkan pengetahuan secara mandiri (Hamzah, 2010).

Pada siklus II, guru mengoptimalkan pembelajaran dengan cara selalu memberi pengawasan yang baik dan selalu mendatangi setiap kelompok sampai peserta didik nyaman dan percaya diri untuk melakukan setiap fase-fase pembelajaran dengan baik. Guru juga tidak memburu waktu untuk menyelesaikan materi, tetapi mendampingi peserta didik jika terdapat materi yang belum dipahami. Tindakan perbaikan ini mendapat respons yang baik dari peserta didik. Hal ini ditunjukkan dengan sikap peserta didik yang lebih fokus dan berani melakukan eksperimen. Selain itu, peserta didik menjadi lebih aktif dalam berdiskusi dalam kelompok masing-masing.

Peserta didk belajar untuk membangun pengetahuan sendiri dengan berdikusi dan menemukan konsep atau prinsip melalui eksperimen. Hal ini akan membuat peserta didik memahami konsep secara lebih mendalam sehingga dapat mengaplikasikan konsep fisika dalam kehidupan sehari-hari. Pemahaman yang baru menuntut aktivitas kreatif produktif dalam konteks nyata yang mendorong peserta didik berpikir lalu mendemonstrasikannya (Mursell \& Nasution, 2010).

Ketika memasuki kegiatan presentasi, peserta didik sudah mampu memberi tanggapan dan respons yang baik secara menyeluruh. Hal ini terlihat dari kegiatan tanya jawab bukan hanya dari peserta didik yang pandai saja, tetapi peserta yang memiliki kemampuan rendah juga mengajukan dan menanggapi pertanyaan. Perubahan tersebut menunjukkan rasa percaya diri yang dibangun di kelompok. Selain itu, peserta didik sudah memahami konsep dan prinsip materi sehingga dapat bertanya dan menanggapi pertanyaan teman sekelasnya. Peserta didik juga mampu membuat kesimpulan dengan baik.

Perubahan-perubahan yang terjadi dari siklus I ke siklus II adalah cara pandang peserta didik terhadap belajar yang awalnya menerima pengetahuan pengetahuan dari guru, menjadi belajar mengali pengetahuan di dalam kelompok. Diskusi tidak hanya dilakukan untuk memelajari sesuatu yang baru, akan tetapi juga mentransfer apa yang telah dipelajari (Riyanto, 2015). 
Peserta didik terlihat lebih aktif dan kreatif karena guru mempersiapkan strategi di siklus II dengan pertanyaan yang lebih mudah dipahami dan juga meminta peserta didik membaca berbagai literatur agar peserta didik mempunyai bekal ketika mengikuti pelajaran. Presentasi juga berjalan baik karena peserta didik sudah banyak memberikan tanggapan dan usulan untuk menyelesaikan masalah yang dibahas dalam lembar kerja.

Pada siklus II, guru secara aktif memberi pengawasan dengan memberi penjelasanakan tahapan model pembelajaran discovery learning sekaligus menyampaikan tujuan kegiatan seperti yang terdapat dalam lembar kerja sehingga membuat peserta didik fokus dan bersemangat. Peserta didik akan belajar dengan perhatian penuh ketika memahami tujuan yang harus dicapai serta mengerti apa yang harus dilakukan.

\section{KESIMPULAN}

Model pembelajaran discovery learning dapat meningkatkan motivasi dan hasil belajar peserta didik. Peningkatan hasil belajar fisika terjadi dari nilai rata-rata 65.11 pada siklus I menjadi 78.47 pada siklus II. Peningkatan hasil belajar peserta didik terjadi secara singnifikan, dibuktikn dengan bertambahnya peserta didik yang mencapai ketuntasan belajar minimum dari $38.88 \%$ pada siklus I menjadi $91.7 \%$ pada siklus II. Model pembelajaran discovery learning juga mendapat respons positif dari peserta didik dengan persentase rata-rata lebih dari $70 \%$. Berdasarkan hasil penelitian dapat disimpulkan bahwa model pembelajaran discovery learning efektif meningkatkan motivasi dan hasil belajar peserta didik kelas XI IPA 3 SMA N 6 Pekanbaru.

\section{UCAPAN TERIMA KASIH}

Ucapan terima kasih kepada SMA N 6 Pekanbaru atas dukungan dalam pelaksanaan penelitian ini.

\section{DAFTAR PUSTAKA}

Aprilia, L. \& Mulyaningsih, S., 2014. Penerapan Perangkat Pembelajaran Materi Kalor melalui Pendekatan Saintifik dengan Model Pembelajaran Guided Discovery Kelas X SMA. Jurnal Inovasi Pendidikan Fisika, 3(3): 1-5. Arikunto, S., Suhardjoho, \& Supardi, 2010. Penelitian Tindakan Kelas. Jakarta: Bumi Aksara. 
Decaprio, R., 2002. Tips Mengelola Laboratorium Sekolah. Yogyakarta: Diva Press.

Destalina, Ali, M. \& Palloan, P., 2019. Efektivitas Penerapan Discovery Learning Pada Pembelajaran Sains Berorientasi Inquiry Terhadap Pemahaman

Konsep Fisika Peserta Didik Kelas XI IPA SMA Negeri 13 Makasar. Jurnal Sains dan Pendidikan Fisika, 15(1): 1-7.

Fitri, M. \& Derlina, 2015. Pengaruh Model Pembelajaran Discovery Learning Terhadap Hasil Belajar Peserta didik pada MATERI Pokok Suhu dan Kalor. Jurnal Inpafi, 3(2): 89-96.

Hamzah, 2010. Teori Motivasi dan Pengukurannya Analisis di Bidang Pendidikan. Jakarta: Bumi Aksara.

Hanafi, 2016. The Effect of Discovery Learning Method Application on Increasing Students' Listening Outcome and Social Attitude. Dinamika Ilmu, 16(2): 291306.

Khamidah, N., Winarto \& Mustikasari, V.R. 2019. Discovery Learning:
Penerapan Dalam

Pembelajaran IPA Berbantuan Bahan Ajar

Digital Interaktif untuk

Meningkatkan Prestasi

Belajar Peserta Didik. Jurnal Pendidikan IPA Veteran, 3(1): 87-99.

Kusuma, T., Indrawati \& Harijanto, A. 2015. Model

Discovery Learning disertai Teknik Probing Prompting dalam Pembelajaran Fisika di MA. Jurnal Pendidikan Fisika, 3(4): 336-341.

Mursell, J. \& Nasution. 2010. Mengajar dengan Sukses (Successful Teaching. Jakarta: Bumi Aksara.

Riyanto, Y. 2015. Paradigma Baru Pembelajaran Sebagai Referensi Guru/Pendidik dalam Implementasi

Pembelajaran yang Efektif dan Berkualitas. Jakarta: Kencana Prenada Medis Group.

Sahara, L. \& Sani, R. 2016. Pengaruh Metode Pembelajaran Penemuan Terbimbing terhadap Hasil Belajar dan Aktivitas Peserta Didik pada Materi Pokok Suhu dan Kalor di SMA Negeri Limapuluh. Jurnal Inpafi, 4(2): 1-6. 
Saidatunnisa, Hamid, A. \& Wahyuni, $\quad$ A. 2016. Penerapan Model Pembelajaran Discovery Tipe Guided Discovery dalam Upaya Meningkatkan Hasil Belajar Fisika Peserta didik Kelas XI MIPA 2 di SMAN 16 Banda Aceh. Jurnal Ilmiah Mahapesertadidik Pendidikan Fisika, 2(1): 2029.

Sanjaya, 2008. Strategi Pembelajaran Berorientasi Standar Proses Pendidikan. Jakarta: Kencana Prenada Media Group.

Sanjaya, W. 2005. Pembelajaran dalam Implementasi

Kurikulum Berbasis Kompetensi. Bandung: Kencana Prenada Media Group.

Sari, P.I. \& Harjono, A. 2016. Penggunaan Discovery Learning Berbantuan Laboratorium Virtual pada Penguasaan Konsep Fisika Peserta didik. Jurnal Pendidikan Fisika dan Teknologi, II (4): 176-182.
Schuchard, A.M., Tekkumru-Kisa, M. \& Schunn, C.D. 2017. How Much Professional Development Is Needed With Educative Curriculum Materials? It Depends Upon The Intended Student Learning Outcomes. Science Education, 101(6): 10151033.

Singgih, H.A. \& Suparwoto. 2018. Pengembangan Media Belajar Mandiri Berbasis Aplikasi WhatsApp untuk Meningkatkan Motivasi dan Hasil Belajar Fisika Kelas XI SMA N 1 Purwokerto. Jurnal Pendidikan Fisika, 7(1): 3238.

Sutikno, S., 2013. Belajar dan Pembelajaran. Lombok: Holistica.

Tompo, B., Ahmad, A. \& Muris, M. 2016. The Development of Discovery-Inquiry Learning Model to Reduce the Science Misconceptions of Junior High School Students. International Journal of Junior High School Students, 11(12): 5676-5686. 